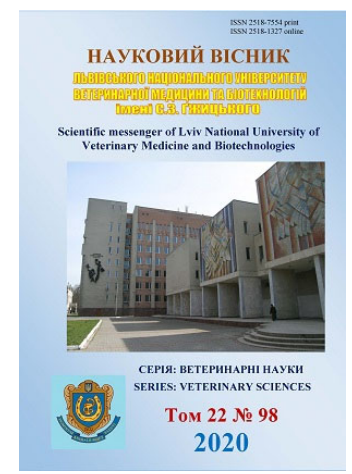

\author{
Науковий вісник Дьвівського національного університету \\ ветеринарної медицини та біотехнологій імені С.3. Гжицького. \\ Серія: Ветеринарні науки \\ Scientific Messenger of Lviv National University \\ of Veterinary Medicine and Biotechnologies. \\ Series: Veterinary sciences
}

UDC 636.52/.58:612.017:615.9

\title{
Correction of the state of antioxidant protection system of the fowl's organism under the circumstances of being poisoned by Derosal
}

\author{
O. S. Kochevenko, I. O. Zhukova, O. M. Bobrytska, I. O. Kostiuk, L. A. Vodopyanova
}

Kharkiv State Zooveterinary Academy, Kharkiv, Ukraine

Article info

Received 16.03.2020

Received in revised form 20.04.2020

Accepted 21.04.2020

Kharkiv state zooveterinary academy, Mala Danilivka, Dergachi district, Kharkiv region, 62341, Ukraine.

Tel.: +38-095-773-65-26

E-mail:patfiz@zoovet.kh.ua

Kochevenko, O. S., Zhukova, I. O., Bobrytska, O. M., Kostiuk, I. O., \& Vodopyanova, L. A. (2020). Correction of the state of antioxidant protection system of the fowl's organism under the circumstances of being poisoned by Derosal. Scientific Messenger of Lviv National University of Veterinary Medicine and Biotechnologies. Series: Veterinary sciences, 22(98), 46-50. doi: $10.32718 /$ nvlvet 9808

In fact, Free radical oxidation is one of the required factors of homeostasis as far as the active forms of oxygen, which have unpaired electron, perform useful functions, they are necessary intermediaries of numerous processes of normal cells' functioning such as biosynthesis of prostaglandins and leukotriene as well as other biologically active substances. Also, they take part in pathological processes such as: inflammation, fever and others. Free radical oxidation is the process of direct oxygen transferring to the substrate forming peroxide, ketones, aldehydes, etc. Some amino acids, proteins, water and carbohydrates prone to the processes of peroxidation, but crucial place is granted to lipids at the expanse of fatty acids which are included to their composition. The article highlights the information concerning the analysis of the state of antioxidant system of hens in the process of feeding them with subtoxic doses of fungicide of Derosal (BAYER, Germany) (0.1 LD 50 for a fowl, $900 \mathrm{mg} / \mathrm{kg}$ of the body mass) which active ingredient is benzimidazole carbamate (carbendazim, BMC). It presents the changes of these indicators in the process of using pharmacological and natural antioxidants. The analysis has figured out that giving Derosal to the hens without corrections (II group) has been followed with the activation of the process of lipids' peroxidation $(P O L)$ in the blood plasma, that is followed with the increase of concentration of primary and secondary lipoperoxidation products - diene conjugates (DC) and TBA-active products on the average up to 21.0 $25.0 \%$, catalase activity - up to $38.5 \%$ and decrease of superoxide dismutase activity (SOD) up to $21.8 \%$ and AOA - up to $17.8 \%$, that shows the adverse effects of pesticides on the system of antioxidant protection of the organism. In the fowls' groups III, IV and V the adding of antioxidant E-selenium, ascorbic acid and thermally untreated buckwheat seeds as the source of quercetins and anthocyanins has led to the induction of antioxidant resources that is shown by the decrease in comparison with the control of content of diene conjugates, malonic dialdehyde and catalase (in average up to 13.6-33.6-18.0\% accordingly) and compensatory strengthening of superoxide dismutase activity and general activity of antioxidant (AOA) on the average up to 44.9-72.1-76.5\% and 15.3-13.4-21.7\% accordingly. In comparison with group II the activity of catalase has been lower as well as the activity of superoxide dismutase has been higher in all the groups almost in 1.5-2 times $(P \leq 0.001)$. catalase.

Key words: hens, lipids' peroxidation, diene conjugates, malonic dialdehyde, superoxide dismutase,

\section{Корекція стану системи антиоксидантного захисту організму птиці за отрусння Дерозалом}

О. С. Кочевенко, І. О. Жукова, О. М. Бобрицька, І. О. Костюк, Л. А. Водоп’янова

Харківська державна зооветеринарна академія, м. Харків, Україна 
Вільнорадикальне окиснення в нормі є одним із необхідних факторів гомеостазу, оскільки активні форми кисню, щзо мають неспарений електрон, виконують корисні функиї, вони є необхідними посередниками багатьох процесів нормального функиіонування клітин, таких як біосинтез простагландинів, лейкотрієнів та інших біологічно активних речовин, а також беруть участь у патологічних процесах, таких як запалення, гарячка та ін. ВРО є прочесом безпосереднього переносу кисню на субстрат з утворенням перекисів, кетонів, альдегідів тощуо. До прочесів пероксидного окиснення схильні деякі амінокислоти, білки, вода, вуглеводи, але в організмі вирішальне значення мають ліпіди за рахунок ненасичених жирних кислот, що входять до їх складу. У статті наведені дані шеодо дослідження стану антиоксидантної системи курей за згодовування їм субтоксичних доз фунгіииду Дерозалу (ВАҮЕR, Німеччина) (0,1 ЛД5о для птиці, 900 мг/кг маси тіла), активним інгредієнтом якого є бензімідазолкарбамат (карбендазим, БМК), а також зміни цих показників за застосування фармакологічних та натуральних антиоксидантів. Дослідженнями встановлено, шчо задавання курям Дерозалу без коректантів (II група) супроводжувалось активацією в плазмі крові процесів пероксидного окиснення ліпідів (ПОЛ) з підвищенням концентрації первинних і кінцевих продуктів ліпопероксидації-дієнових кон'югатів (ДК) $і$ ТБКактивних продуктів у середньому на 21,0-25,0\%, активності каталази - на 38,5\% та зниженням активності супероксиддисмутази (СОД) на 21,8\% і АОА - на 17,8\%, що свідчить про несприятливий вплив пестициду на систему антиоксидантного захисту організму. У III, IV i V групах птиці додавання антиоксидантів Е-селену, аскорбінової кислоти і термічно необробленого насіння гречки як джерела кверцетину і антоціанів приводило до індукції антиокиснювальних ресурсів, про шцо свідчить зниження порівняно з контролем вмісту дієнових кон'югатів, ТБК-активних продуктів та активності каталази (у середньому на 13,6-33,6-18,0 \% відповідно) та компенсаторне підсилення активності супероксиддисмутази $і$ загальної антиоксидантної активності (АОА) у середньому на 44,9-72,1-76,5\% та 15,3-13,4-21,7\% відповідно. Порівняно з показниками ІІ групи активність каталази була нижчою, а активність СОД - вищзою в усіх групах майже у $1,5-2$ рази $(P \leq 0,001)$.

Ключові слова: кури, пероксидне окиснення ліпідів, дієнові кон'югати, ТБК-активні продукти, супероксиддисмутаза, каталаза.

\section{Ветуп}

Вільнорадикальне окиснення (ВРО) в нормі є одним із необхідних факторів гомеостазу, оскільки активні форми кисню (АФК), що мають неспарений електрон, виконують корисні функції, наприклад, за запальних процесів лейкоцити за їх участю руйнують фагоцитовані бактерії (Zhang et al., 2013; Warnatsch et al., 2017; Chelombit'ko, 2018), вони є необхідними посередниками багатьох процесів нормального функціонування клітин, таких як біосинтез простагландинів, лейкотрієнів та інших біологічно активних речовин. ВРО є процесом безпосереднього переносу кисню на субстрат з утворенням перекисів, кетонів, альдегідів, причому ці реакції є ланцюговими. До процесів пероксидного окиснення схильні деякі амінокислоти, білки, вода, вуглеводи, але в організмі вирішальне значення мають ліпіди за рахунок ненасичених жирних кислот (НЖК), що входять до їх складу (Min \& Boff, 2006; Valko et al., 2007; Grymak et al., 2020; Slobodian \& Hutyi, 2020).

Поряд з позитивним впливом надмірне накопичення продуктів вільнорадикального і пероксидного окиснення є важливим етіологічним фактором виникнення ряду хронічних захворювань, в тому числі й за отруєння пестицидами, оскільки вони забирають електрони в молекул і таким чином пошкоджують оболонки клітин, ДНК, складових хряща та ін. В результаті появи у гідрофобному шарі мембран гідрофільних зон за рахунок утворення гідропероксидів жирних кислот у клітини можуть проникати вода, іони Натрію, Кальцію, що призводить до набрякання клітин, органел i їх руйнування. Активація пероксидного окиснення характерна для багатьох захворювань, воно активується також у тканинах, які піддалися спочатку ішемії, а потім реоксигенації, що відбувається, наприклад, при спазмі коронарних артерій і подальшому їх розширенні, й тому вивчення впливу лікарських препаратів і біологічно активних добавок, які мають антиоксидантну дію на організм, для корекції ряду станів, що викликані або супроводжуються окисним стресом, є актуальним (Florence, 1995; Men'shchikova et al., 2006; Grivennikova \& Vinogradov, 2013; Lotots'ka, 2013; Gutyj et al., 2018; Kharechkina \& Nikiforova, 2018; Martyshuk \& Gutyj, 2019).

Пошкоджуючому ефекту вільних радикалів (ВР), АФК протистоїть система протиокиснювального захисту, головною діючою ланкою якого є антиоксиданти - сполуки, які здатні гальмувати, зменшувати інтенсивність ВРО, нейтралізувати ВР шляхом обміну свого атома водню на кисень вільних радикалів. У виведенні ВР і радикальних форм антиоксиданти відіграють роль системи природної детоксикації. Окрім ферментних антиоксидантів, які утворюються в організмі у відповідь на реакцію пероксидного окиснення ліпідів, відомі й неферментні їх форми: аскорбінова кислота (вітамін С), токофероли (вітамін Е), ßкаротин (провітамін А), лікопін, поліфеноли: флавін і флавоноїди (рутин, гесперидин, гіперозид, кверцетин, кемпферол та апігенін), таніни і антоціани. Особливість функціонування АОС у різних органах і тканинах визначається генотипом, а також залежить від надходження в організм індукторів ВРО, забезпеченості біоантиоксидантами (а-токоферолом, аскорбіновою кислотою, b-каротином, селеном). Тривала інтенсифікація ВРО призводить до виснаження АОС (дефіциту вітамінів Е, C, b-каротину, глутатіону, селену, зниженню активності СОД, каталази, глутатіонпероксидази та ін.) (Danchenko, 2002; Droshnev et al., 2005; Leshovs'ka et al., 2007; Varkholiak \& Gutyj, 2019).

Особливе значення мають антиоксидантні властивості кверцетину - природної сполуки із числа флавоноїдів, яка відповідає за колір деяких овочів і фруктів. Згідно з літературними даними, найбільше його вміщується у зеленій гречці (до 8 \%), а антиоксидантна активність разом із проантоцианідином вища, ніж у багатьох інших продуктах (Boots et al., 2008).

Метою дослідження було встановлення інтенсивності процесів пероксидного окиснення ліпідів і стану параметрів антиоксидантної системи курей, яким згодовували субтоксичні дози фунгіциду Дерозалу, а також зміну цих показників за застосування фармакологічних та натуральних антиоксидантів. 


\section{Матеріал і методи досліджень}

У досліді використали курей м'ясо-яєчної породи Род Айланд, лінії 38, 30-добового віку, масою 10001200 г, які були поділені на 1 контрольну групу (I група, $\mathrm{n}=10$ ) і 4 дослідних (II, III, IV i V, n = 40). Птицю годували за двома раціонами: першим - до 40добового віку, а другим - від 40 діб і до кінця досліду (60 діб) (Ageyev et al., 1987). Кури II, III, IV i V дослідних груп одержували щодня протягом 60 діб з комбікормом препарат Дерозал (BAYER, Німеччина) активним інгредієнтом якого є бензімідазолкарбамат (карбендазим, БМК), у формі готової 50 \% водної суспензії, в дозі 900 мг на 1 кг маси тіла (0,1 ЛД 50 для птиці) (Kochevenko \& Zhukova, 2014). Крім того, птиця II групи антиоксиданти не отримувала, III групи одержувала препарат “Е-селен” 3 питною водою в розведенні 1:100 в дозі 1 мл/кг маси тіла або 2 мл/л води 1 раз на 30 діб, IV групи - аскорбінову кислоту в дозі - 100 мг/кг корму щоденно і V групи - мелене термічно необроблене зерно гречки (“зелена гречка”) як джерело кверцетину із розрахунку 0,2 г/кг маси тіла щоденно 3 кормом. Птиці контрольної групи пестицид і препарати не вводили.

Інтенсивність процесів пероксидного окиснення ліпідів (ПОЛ) оцінювали через 30 і 60 діб за визначення у плазмі крові концентрації його продуктів дієнових кон'югатів (ДК) і ТБК-активних продуктів (Havrylova \& Myshkorudnaya, 1985), стану показників антиокиснювальної системи (АОС) (Korolyuk, 1988; Stegniy et al., 2007), рівня загальної антиокиснюваль- ної активності (AOA) ліпідів плазми крові (Havrylova \& Myshkorudnaya, 1985; Klebanov et al., 1988), спектру поглинання ТБК-активних продуктів. Результати досліджень оброблені статистично 3 використанням пакета програм Microsoft Excel 2003 (for Windows $\mathrm{XP)}$.

\section{Результати та їх обговорення}

Протягом досліду птиця контрольної і дослідних груп була клінічно здоровою, тобто ніяких ознак отруєння не спостерігали.

Дослідження динаміки інтенсивності пероксидного окиснення ліпідів у плазмі крові птиці показало, що в II групі, яка отримувала тільки Дерозал, на 30 i 60 добу концентрація первинних і кінцевих продуктів ліпопероксидації - дієнових кон'югатів і ТБКактивних продуктів перевищувала контрольні показники на $14,6-18,2 \%$ та 27,8-31,5 \% (P $\leq 0,05)$ відповідно (табл. 1). В III, IV i V групах у ці ж строки досліду вміст ДК був нижчим за контроль на 11,6$12,0 \%$; 9,3-10,3\% i 19,5-38,1\% (P $\leq 0,01)$ i ТБКактивних продуктів - на 24,9-37,5 \%, 38,5-47,2 \% і 35,9-64,8 \% (P $\leq 0,05 ; \mathrm{P} \leq 0,01)$ відповідно.

Порівняно з II групою концентрація ДК і ТБКактивних продуктів у III, IV i V дослідних групах була також достовірно нижчою відповідно на 30 добу - на $27,9-59,5 \%, 25,2-76,9 \%$ і 36,8-73,68 \% та на 60 добу - на 39,7-80,8 \%, 28,3-65,9\% і 60,5-86,8 \% (P $\leq 0,05$; $\mathrm{P} \leq 0,01)$.

\section{Таблица 1}

Рівень показників інтенсивності процесів ПОЛ у плазмі крові курей за додавання Дерозалу і антиоксидантів $(\mathrm{M} \pm \mathrm{m})$

\begin{tabular}{|c|c|c|c|}
\hline \multirow{2}{*}{$\begin{array}{c}\text { Група курей, } \\
(\mathrm{n}=10)\end{array}$} & \multirow{2}{*}{$\begin{array}{c}\text { Термін досліджень, } \\
\text { діб }\end{array}$} & \multicolumn{2}{|c|}{ Інтенсивність ПОЛ, продукти ліпопероксидації } \\
\hline & & ДК, мкмоль/л & ТБК-активні продукти, $\Delta Д$ \\
\hline \multirow{2}{*}{ 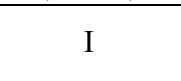 } & 30 & $22,10 \pm 0,09$ & $4,32 \pm 0,08$ \\
\hline & 60 & $24,44 \pm 0,03$ & $4,73 \pm 0,01$ \\
\hline \multirow{2}{*}{ II } & 30 & $25,32 \pm 0,15^{*}$ & $5,52 \pm 0,09^{*}$ \\
\hline & 60 & $28,41 \pm 0,11^{*}$ & $6,22 \pm 0,04 * *$ \\
\hline \multirow{2}{*}{ III } & 30 & $19,80 \pm 0,07 * \#$ & $3,46 \pm 0,08^{*} \#$ \\
\hline & 60 & $20,33 \pm 0,16^{* * \# \#}$ & $3,44 \pm 0,07 * \#$ \\
\hline \multirow{2}{*}{ IV } & 30 & $20,22 \pm 0,10 * * \# \#$ & $3,12 \pm 0,01 * * \# \#$ \\
\hline & 60 & $22,15 \pm 0,05^{* *} \# \#$ & $3,75 \pm 0,02 * * \# \#$ \\
\hline \multirow{2}{*}{$\mathrm{V}$} & 30 & $18,50 \pm 0,04 * * \# \#$ & $3,18 \pm 0,03 * * \# \# *$ \\
\hline & 60 & $17,70 \pm 0,08 * * \# \#$ & $3,33 \pm 0,08 * * \#$ \\
\hline
\end{tabular}

Примітки: * - $\mathrm{P} \leq 0,05,{ }^{* *}-\mathrm{P} \leq 0,01$ щодо показників контролю; ${ }^{*}-\mathrm{P} \leq 0,05 ;{ }^{\# \#}-\mathrm{P} \leq 0,01$ - щодо показників II групи

Поєднана робота антиоксидантних ензимів є фактором, який визначає концентрацію продуктів ПОЛ у клітинах живого організму. Дослідом встановлено, що у сироватці крові дослідних курей II групи достовірно підвищувалась активність каталази щодо показників контрольної групи на $44,1 \%$ i 33,0 \% (P $\leq 0,01)$ відповідно на 30 і 60 добу досліджень, а активність супероксиддисмутази (СОД), навпаки, знижувалась відповідно на 29,4-14,3 \% у ті ж періоди $(\mathrm{P} \leq 0,05)$, тобто у цій групі зростала активність, яка каталізує реакцію дисмутації супероксидних радика- лів 3 утворенням високотоксичного агента - перекису водню (табл. 2).

У III, IV i V групах курей, яким разом з Дерозалом додавали антиоксидантні препарати, активність каталази, навпаки, була нижчою за контроль на 8,4-19,4$31,5 \%$ на 30 добу i на $0-26,3-36,4 \%$ (P $\leq 0,05$; $\mathrm{P} \leq 0,01)$ - на 60 добу досліджень, а активність СОД, навпаки, підвищувалась у ті ж терміни на 54,5-59,1$77,3 \%$ і на $35,4-85,0-75,8 \%(\mathrm{P} \leq 0,05 ; \mathrm{P} \leq 0,01)$ відповідно. Порівняно з показниками II групи активність каталази була нижчою, а активність СОД - вищою в усіх групах майже у $1,5-2$ рази $(\mathrm{P} \leq 0,001)$. 
Таблиця 2

Функціональна активність АОС у плазмі крові курей за додавання Дерозалу і введення препаратів $(\mathrm{M} \pm \mathrm{m})$

\begin{tabular}{|c|c|c|}
\hline \multirow{2}{*}{$\begin{array}{c}\text { Группа птиці } \\
(\mathrm{n}=10)\end{array}$} & \multicolumn{2}{|c|}{ Термін досліджень, діб } \\
\hline & 30 & 60 \\
\hline \multicolumn{3}{|c|}{ Активність каталази, нмоль $\mathrm{H}_{2} \mathrm{O}_{2} /$ сек мг білка } \\
\hline I & $77,3 \pm 0,9$ & $75,4 \pm 0,8$ \\
\hline II & $111,4 \pm 1,1^{*}$ & $100,2 \pm 1,0^{*}$ \\
\hline III & $71,3 \pm 0,5^{*}$ & $75,5 \pm 0,9$ \\
\hline IV & $64,7 \pm 1,0 * *$ & $59,7 \pm 1,2 * *$ \\
\hline $\mathrm{V}$ & $58,8 \pm 0,7 * *$ & $55,3 \pm 0,7 * *$ \\
\hline \multicolumn{3}{|c|}{ Активність СОД, од.акт./мг білка } \\
\hline I & $2,2 \pm 0,02$ & $2,4 \pm 0,07$ \\
\hline II & $1,7 \pm 0,13^{*}$ & $2,1 \pm 0,03^{*}$ \\
\hline III & $3,4 \pm 0,03 * * \#$ & $3,25 \pm 0,11 * \#$ \\
\hline IV & $3,5 \pm 0,02 * * \#$ & $4,44 \pm 0,10^{* * \#}$ \\
\hline $\mathrm{V}$ & $3,9 \pm 0,01 * * \#$ & $4,22 \pm 0,09 * * \#$ \\
\hline \multicolumn{3}{|c|}{ Загальна АОА, \% інгібіції } \\
\hline I & $65,3 \pm 0,9$ & $66,4 \pm 1,0$ \\
\hline II & $57,7 \pm 0,6^{*}$ & $54,2 \pm 1,6^{* *}$ \\
\hline III & $74,1 \pm 1,5^{*} \#$ & $77,7 \pm 1,5^{* *} \#$ \\
\hline IV & $73,9 \pm 1,6^{*} \#$ & $75,4 \pm 2,1 * \#$ \\
\hline $\mathrm{V}$ & $80,2 \pm 0,8 * * \#$ & $80,0 \pm 0,8^{*} \#$ \\
\hline
\end{tabular}

Примітки: ${ }^{*}-\mathrm{P} \leq 0,05,{ }^{* *}-\mathrm{P} \leq 0,01$ щодо показників контролю; ${ }^{\#}-\mathrm{P} \leq 0,01$; $^{\#}-\mathrm{P} \leq 0,01$ - щодо показників II групи

За згодовування птиці Дерозалу без корекційних добавок (II група) визначено достовірне зниження рівня показників загальної АОА ліпідів плазми крові щодо контролю на 13,2-22,5 \% на 30 і 60 добу відповідно. За додавання до раціону антиоксидантів у всі терміни досліджень у III, IV і V групах виявлено підвищення рівня загальної АОА на 13,5-13,2-22,8 \% на 30 добу і на 17,0-13,6-20,5 - на 60 добу відповідно. Порівняно з II групою ці показники були також достовірно вищими на 28,4-13,2-40,0 \% і на 43,4-39,1$47,6 \%$ (P $\leq 0,01, \mathrm{P} \leq 0,001)$ відповідно у перший i другий етап досліджень.

\section{Висновки}

Дослідженнями встановлено, що задавання курям Дерозалу без коректантів (II група) супроводжувалось активацією в плазмі крові процесів ПОЛ, підвищенням активності каталази, зниженням активності СОД і АОА, що свідчить про несприятливий вплив пестициду на систему антиоксидантного захисту організму. У III, IV i V групах птиці додавання антиоксидантів Еселену, аскорбінової кислоти і термічно необробленого насіння гречки як джерела кверцетину і антоціанів приводило до індукції антиокиснювальних ресурсів, про що свідчить зниження до фізіологічної норми активності каталази і компенсаторне підсилення активності супероксиддисмутази і загальної АОА.

\section{References}

Ageyev, V. N. Yegorov, I. A., Okolelova, T. M., \& Pan'kov, P. N. (1987). Kormleniye ptitsy: Spravochnik. M.: Agropromizdat (in Russian).

Bahlay, O. M., Murs'ka, S. D. Hutyy, B. V. \& Hufriy, D. F. (2011). Systema antyoksydantnoho zakhystu ta perekysne okysnennya lipidiv orhanizmu tvaryn. Nau- kovyy visnyk LNUVMBT imeni S. Z. Gzhyts'koho, 13, 4(50), 3-11 (in Ukrainian).

Boots, A. W., Haenen, G. R., \& Bast, A. (2008). Health effects of quercetin: from antioxidant to nutraceutical. Eur J Pharmacol., 585(2-3), 325-337. doi: 10.1016/j.ejphar.2008.03.008.

Chelombit'ko, M. A. (2018). Rol' aktivnykh form kisloroda v vospalenii. Miniobzor. Vestnik Moskovskogo universiteta. Seriya 16. Biologiya, 73(4), 242-246 (in Russian).

Danchenko, G. V. (2002). Novi aspekty mehanizmu biologichnoi' dii' vitaminu E, jogo aktyvnyh metabolitiv ta pohidnyh. Ukrai'ns'kyj biohimichnyj zhurnal, 74(4), 8-12 (in Ukrainian).

Droshnev, A. E., Borisova, M. N., \& Kostromitinov, N. A. (2005). Vlijanie vitamina E na pokazateli perekisnogo okislenija lipidov i antioksidantnoj zashhity u ryb pri stresse. Mizhvidomchij tematichnij naukovij zbirnik "Veterinarna medicina", 1, 395-398 (in Russian).

Florence, T. M. (1995). The role of free radicals in disease. Aust N. Z. J. Ophthalmol, 23(1), 3-7. doi: 10.1111/j.1442-9071.1995.tb01638.x.

Grivennikova, V. G. \& Vinogradov, A. D. (2013). Generatsiya aktivnykh form kisloroda mitokhondriyami. Uspekhi biologicheskoy khimii, 53, 245-296 (in Russian).

Grymak, Y., Skoromna, O., Stadnytska, O., Sobolev, O., Gutyj, B., Shalovylo, S., Hachak, Y., Grabovska, O., Bushueva, I., Denys, G., Hudyma, V., Pakholkiv, N., Jarochovich, I., Nahirniak, T., Pavliv, O., Farionik, T., \& Bratyuk, V. (2020). Influence of "Thireomagnile" and "Thyrioton" preparations on the antioxidant status of pregnant cows. Ukrainian Journal of Ecology, 10(1), 122-126. doi: 10.15421/2020_19.

Gutyj, B. V., Gufriy, D. F., Binkevych, V. Y., Vasiv, R. O., Demus, N. V., Leskiv, K. Y., Binkevych, O. M., \& Pavliv, O. V. (2018). Influence of cadmium loading 
on glutathione system of antioxidant protection of the bullocks'bodies. Scientific Messenger of Lviv National University of Veterinary Medicine and Biotechnologies, 20(92), 34-40. doi: 10.32718/nvlvet9207.

Havrylova, V. B., \& Myshkorudnaya, M. I. (1985). Spektrofotometrychne vyznachennya vmistu hidroperekisnykh lipidiv u plazmi krovy. Lab. sprava, 3, 33-35 (in Ukrainian).

Kharechkina, Ye. S. \& Nikiforova, A. B. (2018). Mekhanizmy generatsii aktivnykh form kisloroda pri permeabilizatsii mitokhondrial'nykh membran. Sovremennyye problemy nauki i obrazovaniya, 4. doi: 10.17513/spno.27719 (in Russian).

Klebanov, G. I., Babenkova, M. V., \& Teselkin, Yu. O. (1988). Evaluation of antioxidant activity of blood plasma with the use of bile lipoproreids. Labor. service, 5, 59-62 (in Russian).

Kochevenko, O. S., \& Zhukova, I. O. (2014). Hostra toksychnist' karbendazymu dlya kurey. Naukovyy visnyk LNUVMBT, 16, 3(60), 160-165 (in Ukrainian).

Korolyuk, M. A. (1988). Determination of catalase activity. Labor. service, 1, 16-18.

Leshovs'ka, N. M., Mamchuk, N. A., \& Matlah, I. J. (2007). Vplyv vitaminiv A, D3, E, selenu ta interferonu na systemu antyoksydantnogo zahystu ta procesy peroksydnoi' oksydacii' lipidiv u glybokotil'nyh koriv ta i'h teljat. Biologija tvaryn, 9(1-2), 186-189 (in Ukrainian).

Lotots'ka, O. V. (2013). Perekysne okysnennya lipidiv ta antyoksydantnyy zakhyst $\mathrm{u}$ orhanizmi piddoslidnykh tvaryn pid vplyvom subtoksychnykh doz midi na foni vzhyvannya pytnoyi vody z riznym vmistom stearatu kaliyu. Aktual'ni problemy transportnoyi medytsyny, 3(33), 139-145 (in Ukrainian).

Martyshchuk, T. V., \& Gutyi, B. V. (2019). Influence of feed additive "Butaselmevit Plus" on the indicators of rats blood under the conditions of their poisoning with Tetrachloromethane. Theoretical and Applied Veterinary Medicine, 7(2), 79-83. doi: 10.32819/2019.71014.

Martyshuk, T. V., \& Gutyj, B. V. (2019). Influence of feed additive "Butaselmevit-Plus" on antioxidant status of rats in conditions of oxidative stress. Scientific Messenger of Lviv National University of Veterinary
Medicine and Biotechnologies. Series: Agricultural sciences, 21(90), 76-81. doi: 10.32718/nvlvet-a9013.

Men'shchikova, Ye. B., Lankin, V. Z., Zenkov, N. K., Bondar', I. A., Krugovykh, N. F., \& Trufakin, V. A. (2006). Okislitel'nyy stress. Prooksidanty i antioksidanty. M.: Firma "Slovo" (in Russian).

Min, D. B., \& Boff, I. M. (2006). Chemistry and Reaction of Singlet Oxygen in Foods. Comp. Rev. Food Sci. Food Saf., 1(2), 58-72. doi: 10.1111/j.15414337.2002.tb00007.

Slobodian, S. O., \& Hutyi, B. V. (2020). Stan antyoksydantnoi systemy orhanizmu shchuriv v umovakh tryvaloho kadmiievoho i svyntsevoho navantazhennia. Visnyk PDAA, 1, 196-201. doi: 10.31210/visnyk2020.01.25.

Stegniy, B. T., Kovalenko, L. V., \& Romanko, M. E. (2007). Methods of lipid peroxidation intensity evaluation and its regulation in biological objects: methodical recommendations. Kharkiv (in Ukrainian).

Valko, M., Leibfritz, D., Moncol, J., Cronin, M. T., Mazur, M., \& Telser, J. (2007). Free radicals and antioxidants in normal physiological functions and human disease. Int J Biochem Cell Biol., 39(1), 44-84. doi: 10.1016/j.biocel.2006.07.001.

Varkholiak, I. S., \& Gutyj, B. V. (2019). Influence of the preparation "Bendamin" on the indicators of antioxidant protection of rat myocardium in experimental modeling of heart failure. Scientific Messenger of Lviv National University of Veterinary Medicine and Biotechnologies. Series: Veterinary sciences, 21(95), 98-101. doi: 10.32718/nvlvet9518.

Warnatsch, A., Tsourouktsoglou, T. D., Branzk, N., Wang, Q., Reincke, S., Herbst, S., Gutierrez, M., \& Florence T. M. (2017). Reactive Oxygen Species Localization Programs Inflammation to Clear Microbes of Different Size. Immunity, 46(3), 421-432. doi: 10.1016/j.immuni.2017.02.013.

Zhang, Ya., Choksi, S., Chen, K., Pobezinskaya, Ye., Linno, I., \& Liu, Z.-G. (2013). ROS play a critical role in the differentiation of alternatively activated macrophages and the occurrence of tumor-associated macrophages. Cell Res., 23(7), 898-914. doi: $10.1038 /$ cr.2013.75. 